\title{
Vilseledning: Kriget i Ukraina i svenska medier
}

\author{
Stefan Olsson
}

Stockholm: Timbro förlag 2016

238 sider. ISBN: 9789177030232

Omtalt av Andrea Sofie Nilssen [MA, student, Universitetet i Oslo,
andrea.nilssen1@gmail.com]

«Er 'vi' i Sverige utsatt for påvirkning fra et annet land via nyhetene?» Dette spørsmålet er utgangspunktet for statsviteren og frilansskribenten Stefan Olssons studie «Vilseledning». Gjennom å se på et utvalg riksdekkende svenske mediers rapporteringer om krigen i Ukraina, forsøker Olsson å kartlegge hvordan den russiske informasjonskrigføringen kan tenkes å påvirke den svenske nyhetsformidlingen og rapporteringen fra krigen.

Innledningsvis starter Olsson med å slå fast at Sverige er utsatt for en informasjonskrig fra den russiske statens side. Han legger til grunn den russiske generalstabssjefen Valerij Gerasimovs «doktrine», som sier at fremtidens krig vil kjennetegnes ved at den ikke erklæres, at grensene mellom det militære og det sivile viskes ut, og at kampene vil utkjempes i informasjonsrommet - $\mathrm{i}$ tillegg til rent fysisk. Dette ligner det vi i Vesten kaller hybridkrig, hvor tanken er at man benytter seg av andre verktøy enn kun våpenmakt for å føre sin militære kamp. Ett av disse verktøyene er å bruke informasjon for å villede og skjule andre aktiviteter. I Ukraina har for eksempel russisk side forsynt den internasjonale pressen med falsk informasjon som har bidratt til å skjule bruken av tradisjonelle militære midler. På denne måten søker de å villede motstanderen på en slik måte at motstanderen får vanskeligheter med å avgjøre hva som er sant og hva som ikke er sant. Og som Olsson kommer fram til, så har Russland på mange måter lyktes i å villede svenske nyhetsformidlere når det gjelder dekningen av konflikten i Ukraina.

I studien tar Olsson for seg fem ulike episoder i Ukraina-konflikten. I forbindelse med alle disse episodene var russisk propaganda utbredt. Det interessante for Olsson er hvordan de svenske mediene forholdt seg til propagandaen. Lot de seg påvirke direkte eller indirekte av Russlands alternative forklaringer på hva som egentlig skjedde da det malaysiske MH17-flyet styrtet over Ukraina? Og hvordan forholdt de samme mediene seg til president Putin og utenriksminister Lavrovs uttalelser om at det ikke fantes noen regulære russiske styrker i Øst-Ukraina? Olsson vurderer 
også om medienes omtale av de ulike episodene har påvirket sakligheten og upartiskheten hos nyhetsformidlerne. For som Olsson også diskuterer, så er journalister budbringere av fakta som igjen påvirker opinionen og det politiske spillet. En idealtypisk journalist er en person som rapporterer upartisk. Hun eller han beskriver og rapporterer fra konflikten, men er ikke en del av den. Problemet, ifølge Olsson, er at standardmodellen for hvordan rapportering skal utføres i konflikter ikke fungerer optimalt når den møter de russiske desinformasjonskampanjene. Selv om standardmodellen er bra, er den først og fremst tilpasset demokratiske samfunn. Samfunn der tilgangen på informasjon er stor, og det er vanskelig for aktører som vil påvirke nyhetsrapporteringen å få ensidig gehør for akkurat sin versjon. I tillegg gir rapportering fra konfliktområder en ekstra utfordring til medier som ønsker å fremstå som upartiske. Enda større blir utfordringen når partene i konflikten regelrett lyver.

Ifølge Olsson er det ingen tilfeldighet at Russland har valgt å utvikle påvirkningskapasitet $\mathrm{i}$ informasjonssfæren, da mange av metodene som tas $\mathrm{i}$ bruk $\mathrm{i}$ dag er arvegods fra Sovjetunionen. KGB arbeidet også med propaganda, og det finnes derfor i Russland en tradisjon for å forsøke å manipulere informasjonssfæren. Ifølge Olsson er informasjonskrigen initiert fra øverste hold i Russland, så da demonstrasjonene på Majdanplassen kom var Russland godt forberedt på å starte en omfattende kampanje $\mathrm{i}$ informasjonssfæren. Olsson skriver at det vi nå ser, $\mathrm{i}$ alle fall fra Russlands side, er en maktkamp mellom Russland på den ene siden og Vesten på den andre. Den russiske statsledelsen ser på denne maktkampen i geopolitiske termer og frykter for å bli omringet av Vestens forsvarsallianse NATO. Vesten på sin side har gjentatt at de ikke har noen ambisjon om å angripe Russland, men den russiske siden er mistenksom og stoler ikke på disse uttalelsene. Ifølge Olsson er det for å beskytte seg mot denne politiske og militære alliansen at Russland har utviklet sin strategi som går ut på å vinne innflytelse med alle tilgjengelige midler, ikke bare de konvensjonelt militære. Siden Russland er militært underlegne Vesten, så er dette en måte å vinne fordeler i konflikter. Og som Olsson også konkluderer med, så er dette en strategi de på mange måter har lyktes med i den pågående konflikten $\mathrm{i}$ Ukraina.

Olsson tilbyr en interessant studie, som attpåtil til er høyst relevant på flere punkter. Å forsøke å kontrollere virkelighetsbeskrivelsen i mediene har lenge vært et viktig verktøy i den russiske innenrikspolitikken. Det vi ser i forbindelse med konflikten i Ukraina er at denne teknikken også brukes utenfor Russland - noe Olssons studie er et eksempel på. Russland utnytter at mediene i vestlige samfunn ikke kontrolleres av styresmaktene, men tvert imot at styresmaktene benytter seg av mediene som en kilde til pålitelig informasjon om hva som skjer i verden. Dette giør mediene i de vestlige landene til nøkkelen for de som ønsker å påvirke den vestlige samfunnsdebatten og situasjonsforståelsen. På denne arenaen kan derfor Russland spille et mer jevnt spill enn hva de evner på den konvensjonelle militære arenaen. Tilfeldigvis foregår denne utviklingen $\mathrm{i}$ en tid der mediene $\mathrm{i}$ alle de store 
vestlige demokratiene gjennomgår en krise, og det kuttes ned på antall journalister som bedriver grave- og utenriksjournalistikk. Stadig flere finner informasjon via andre kanaler, spesielt sosiale medier. For medienes del krever utfordringen med slik desinformasjon grundig, kildekritisk arbeid. Journalisters fremste oppgave i et demokratisk samfunn er å sile ut løgn og andre tvilsomme påstander før de når den offentlige debatten. Hvordan vestlige samfunn skal forholde seg overfor utenlandske staters propaganda vil være en av demokratiets største utfordringer fremover. 